\title{
Lesotho telecommunications sector reform: an assessment of regulatory governance and substance
}

\author{
Leboli Zachia Thamae \\ Department of Physics and Electronics, \\ National University of Lesotho, \\ P.O. Roma 180, Lesotho \\ Email: zl.thamae@nul.ls \\ Email: thamae@gmail.com
}

\begin{abstract}
This article presents a review and evaluation of the reach the reform and regulation have extended to the Lesotho telecommunications industry since its return to democratic rule in 1993. It is found that the Government of Lesotho has made huge progress in the reform process by privatising the state-owned utility and establishing an autonomous regulatory body with statutory powers to regulate the telecommunications industry. Even though the independence of the regulator has come under question in the past, a more liberal and competitive sector has been encouraged by the gradual replacements of policies and legislation that impeded its growth. Telecommunications services' penetration has improved considerably from $0.75 \%$ in 1995 to $78 \%$ in 2012, spurred by mobile networks. However, the potential of telecommunications development in Lesotho, like in many small developing African countries, has not been fully utilised, especially in the expansion of internet access.
\end{abstract}

Keywords: Lesotho; telecommunications; reform; policy; regulatory governance; regulatory substance.

Reference to this paper should be made as follows: Thamae, L.Z. (2015) 'Lesotho telecommunications sector reform: an assessment of regulatory governance and substance', Int. J. Technology Policy and Law, Vol. 2, No. 1, pp.71-89.

Biographical notes: Leboli Zachia Thamae received his BSc in Physics and Mathematics from the National University of Lesotho (NUL), Lesotho, in 2000, MSc in Communication Engineering from the University of Manchester Institute of Science and Technology (UMIST), UK, in 2002 and $\mathrm{PhD}$ in Microwave and Communication Systems from University of Manchester, UK, in 2009. In 2002, he was appointed as a Lecturer in the Department of Physics and Electronics at NUL. Currently, he is a Senior Lecturer and Head of Department. His research interests include antennas for mobile communications, regulation of infrastructure systems (telecommunications, electricity, water and sewerage) and sustainable product development. He has nine publications in refereed international journals and conferences. 


\section{Introduction}

Many countries in the Southern African region, Lesotho included, commenced major reforms in the 1990s of transforming the telecommunications sector by initiating privatisation of state-owned infrastructure enterprises (Jayakar and Martin, 2012). The main purpose was to introduce market liberalisation in the telecommunications sector, pave the way for establishment of an independent regulator and attract private sector investment as advocated by the World Bank (Wallsten, 2001; Stovring, 2004) and facilitated by the Southern African Development Community (McCormick, 2003). This move would help address the huge gaps in telecommunications and information technology infrastructure that still exist in many developing African states compared to the rest of the world owing to low levels of income (Henten, 2004). However, Stovring (2004) contests that the design of the reform packages was largely the result of external influence from international organisations with conditional ties in the context of good governance via donor-financed programmes, which the developing countries formally accepted and immediately subverted to some degree with various results. Regardless of the adjustments, the regulatory reforms still stimulated growth in the telecommunications sector for many developing African states in the last 20 years (Kenny and Keremane, 2007), even though empirical knowledge of their effects in Lesotho as a case study is much less comprehensive.

Lesotho is one of the smallest and least developed economies in Africa with limited resources as evidenced by a modest gross domestic product (GDP) per capita of about US\$ 586 (see Table 1). After going through instabilities between political parties and military regime since independence in 1966, Government of Lesotho (GoL) returned to democratic rule in 1993. Landlocked by the economically dominant South Africa (SA), its economy is highly dependent on it, its currency is pegged to the South African Rand and most of its telecommunications traffic to the rest of the world is routed through SA. Lesotho is divided into 10 districts with the administrative capital Maseru having the highest population density from the estimated 1.9 million inhabitants. Its terrain, scattered across an area of $32,000 \mathrm{~km}^{2}$ (18 times less than the size of Botswana), is characterised by rugged mountainous ranges with the lowlands only accounting for about $25 \%$ of its landmass, leading to huge costs of extending the telecommunications networks to a dispersed and low-income subscriber base. However, this challenge has been addressed in part by the commissioning of mobile cellular networks in place of fixed line networks to achieve the goal of providing services to rural and under-served areas.

Table 1 Lesotho's facts and figures

\begin{tabular}{lc}
\hline Population (LDS 2011) & $1,894,194$ \\
Area & $32,000 \mathrm{~km}^{2}$ \\
GDP (2012) & US\$1, 113 million \\
GDP/Capita (2012) & US\$586 \\
GDP Growth Rate (2012) & $3.7 \%$ \\
Unemployment (2008) & $25.3 \%$ \\
Teledensity - fixed (2012) & $2 \%$ \\
Teledensity - mobile (2012) & $76 \%$ \\
Internet access (2011) & $4.5 \%$ \\
\hline
\end{tabular}

Source: $\operatorname{BoS}(2013)$ and LCA (2012) (N.B. US $\$ 1 \approx$ M9.85) 
With the ICT sector having been identified by Target 8.F in the Millennium Development Goals as a critical sector that can stimulate economic development and address the digital divide (UN, 2000), the GoL has undertaken far-reaching telecommunications reforms towards the target over the last two decades. In addition, as a SADC member state, Lesotho has been poised to promote reform of telecommunications sector for sustainable development and economic growth through the SADC facilitation (McCormick, 2003). Particularly after the return to democratic rule in 1993, telecommunications reform processes have been prominent on the agendas of the GoL. Major developments culminated in the liberalisation of the sector and the establishment of the regulatory agency, allowing private investors and mobile network operators to enter the scene. As evidence of growth, mobile services penetration has improved considerably from $1.1 \%$ in 2000 to $76 \%$ in 2012 . However, the level of access to fixed lines and internet services remains too low as indicated by Figure 1 (LCA, 2009c, 2011; ITU, 2013), particularly outside the capital Maseru.

Figure 1 Growth of fixed and mobile subscribers in Lesotho (see online version for colours)

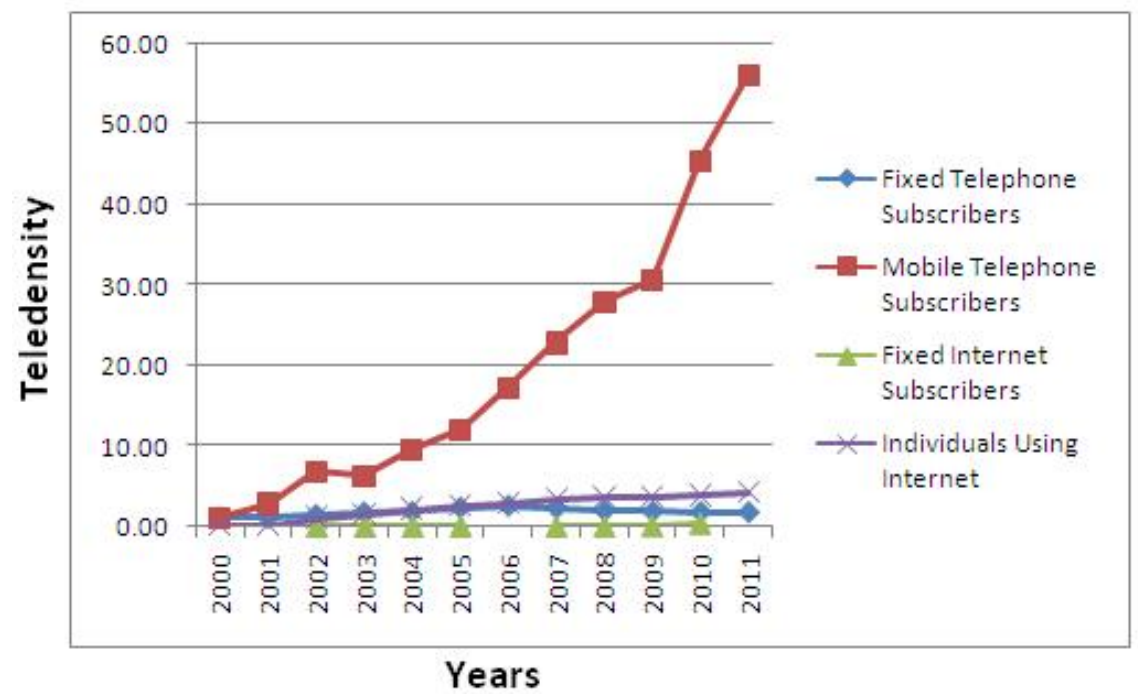

Based on the fact that telecommunications sector development in Lesotho as a small and developing African state is rare, relatively understudied and very little published research is available to explain its growth (Gao and Rafiq, 2009; Waverman and Koutroumpis, 2011; Jayakar and Martin, 2012), this article provides an interesting insight in the chronology of the milestone regulatory reforms undertaken by the GoL in the telecommunications sector during the last two decades and identifies the goals and objectives achieved by creating a competitive telecommunications market. It also evaluates the structure (regulatory governance) and content (regulatory substance) of the telecommunications sector, in keeping with current best practice regulation, through interrogation of applicable policies and legislation to ascertain the regulator's credibility, accountability, transparency and predictability in the independent regulatory decisionmaking processes. It is critical to note that a significant role in the growth of telecommunications sector in developing countries is played by the quality of regulatory 
governance (Jayakar and Martin, 2012), which in turn can guarantee sound regulatory substance.

Previous work analysing the link between telecommunications policy reforms and sectoral performance at international level, and in developing countries in particular is vastly available in literature. Lesotho's performance, in a benchmarking exercise of 142 ITU member countries using telecommunication regulatory governance index (TRGI) and general political transparency, ranked 13th in Sub-Saharan Africa and 78th globally (Waverman and Koutroumpis, 2011). There is a general recognition that good regulatory governance and effective regulatory substance largely drive the performance of the telecommunications sector. In their cross-country comparative assessment of telecommunications regulation using transaction cost economics in Argentina, Chile, Jamaica, the Philippines and the UK, Levy and Spiller (1994) found that the effectiveness of a regulatory framework, and hence its ability to facilitate private investment, varies with a country's political and social institutions. They argue that utilities privatisation and regulatory reform may not always attain improved quality of service and lower prices if arbitrary administrative action is not restrained. However, while exploring the effects of privatisation, competition and regulation on telecommunications performance of 30 African and Latin American countries, Wallsten (2001) concluded that privatisation combined with an independent regulator is positively correlated with telecommunications performance measures.

Another study on the impact of policy reform in telecommunications using data from 86 developing countries across Africa, Asia, Middle East, Latin America and the Caribbean by Fink et al. (2003) has found that both privatisation and competition lead to significant improvements in performance. This finding is corroborated by Gillwald (2005), who argued that international reform models that emphasised privatisation at the expense of competition or regulatory measures have impacted negatively on the policy objective of affordable access to communication services in SA and have inhibited market innovation. Makhaya and Roberts (2003), in reviewing debates on privatisation and international experience on telecommunications services, with a particular emphasis on economic development in SA, concluded that strong capabilities in regulation are important as the gains from telecommunications reforms are dependent on a skilled and empowered regulatory agency.

Nevertheless, most of the existing body of scholarly literature on the assessment of telecommunications policy reforms in developing countries has little or no mention of Lesotho as a case study. Most of the data from the sampled developing African countries excludes Lesotho, leading to a general lack of comparative performance analyses with empirical evidence before and after regulatory reforms, even though the reforms in Lesotho occurred at relatively the same time as in other developing African countries and enough data is now available to begin assessments. Thus, following the identification of liberalisation, privatisation of state-owned monopoly and creating an independent regulatory agency as the key determinants of some policies that have been at the heart of the reforms of the telecommunications industry in developing countries (Gasmi and Virto, 2010), and bearing in mind that different country samples and evaluation techniques lead to differing conclusions about the effects of specific policies (Fink et al., 2003), an attempt is made in this paper to estimate the extent to which the telecommunications sector policy reforms in Lesotho, and the established regulatory governance and regulatory substance, have translated into actual access to services and improved economic development over the period 1995 to 2012. 


\section{Assessment approach}

The assessment approach employed in this case study, adapted from a method recommended by Brown et al. (2006), examines the two important dimensions of regulatory governance and regulatory substance and how they interact to produce the desired outcome (regulatory impact) as depicted in Figure 2. Regulatory governance is defined as the institutional and legal design of the regulatory system which provides the framework for decision-making processes, giving clarity of roles and functions of policymakers, regulator and operators. It encompasses laws, policies, processes and procedures that define the enterprises, actions and parameters that are regulated; the government agencies that make regulatory decisions and the resources and information that must be available to them. Regulatory governance leads to credibility, legitimacy and transparency of regulatory decisions by defining the independence and accountability of the regulator, the relationship between the regulator and the policymakers, and the autonomous processes by which decisions are made.

Figure 2 Regulatory system components (see online version for colours)

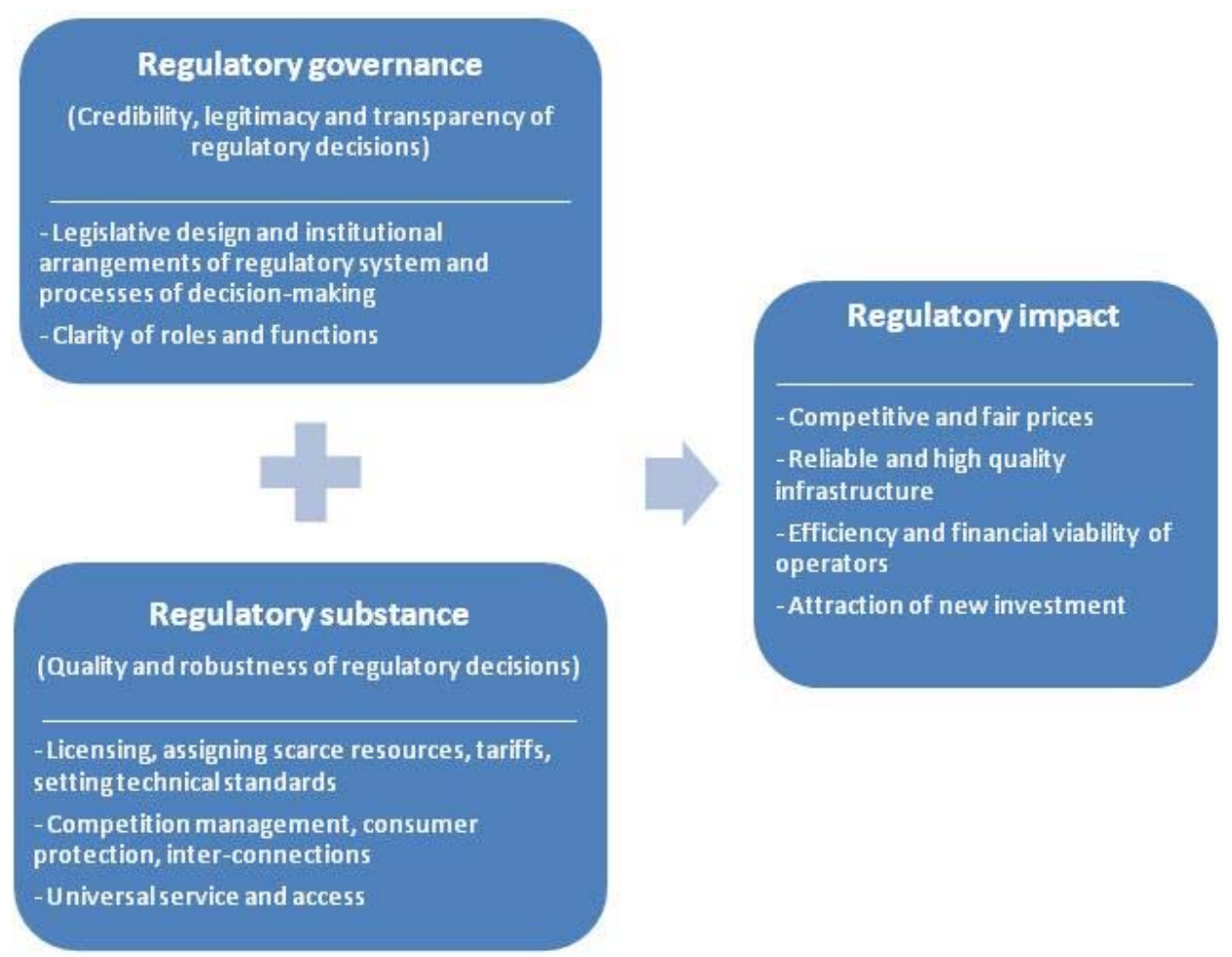

Regulatory substance is the content of regulation and refers to the core regulatory actions and decisions in relation to authorisation (licensing, tariff levels, radio spectrum assignment and numbering allocation), setting technical and quality of service standards, inter-connection obligations, accounting systems and periodic reporting requirements, handling of consumer complaints and promotion of universal service and access. The interaction between regulatory governance and regulatory substance should produce a 
desirable regulatory impact on the sector such as competitively and fairly priced services, reliable and quality infrastructure, efficient and financially viable operators and the timely attraction of new investment to ensure universal access to the population and industry of the country.

Table 2 The assessment approach

\begin{tabular}{|c|c|}
\hline Element & Best practice \\
\hline \multicolumn{2}{|c|}{ Elements of regulatory governance } \\
\hline $\begin{array}{l}\text { Legal and institutional } \\
\text { framework }\end{array}$ & $\begin{array}{l}\text { - Legislation and policy clearly setting the regulator as a statutory } \\
\text { body separate from government, and not accountable to any } \\
\text { supplier of telecommunications services } \\
\text { - Adequate and reliable funding from levies on the sector and fees } \\
\text { charged for specific services } \\
\text { - The decisions of and the procedures used by the regulator shall be } \\
\text { outside the political process and impartial with respect to all market } \\
\text { participants, but should be subject to review by courts }\end{array}$ \\
\hline $\begin{array}{l}\text { Clarity of roles and } \\
\text { functions }\end{array}$ & $\begin{array}{l}\text { - Supporting legal environment for distinct functions performed by } \\
\text { service providers, government (e.g., policy formulation) and } \\
\text { regulatory body (e.g., licensing, radio spectrum management, etc.) }\end{array}$ \\
\hline \multicolumn{2}{|c|}{ Elements of regulatory substance } \\
\hline Licensing/authorisation & $\begin{array}{l}\text { Public availability of licensing criteria, decision-making time for } \\
\text { application processing, terms and conditions of individual licenses }\end{array}$ \\
\hline $\begin{array}{l}\text { Allocation and use of } \\
\text { scarce resources }\end{array}$ & $\begin{array}{l}\text { - Procedures for the allocation and use of scarce resources, including } \\
\text { frequencies, numbers and rights of way, are carried out in an } \\
\text { objective, timely, transparent and non-discriminatory manner }\end{array}$ \\
\hline $\begin{array}{l}\text { Regulating competition } \\
\text { (including tariffs) }\end{array}$ & $\begin{array}{l}\text { - Competitive safeguards for prevention of anti-competitive practices } \\
\text { (e.g., cross-subsidisation, using competitors' information, denial of } \\
\text { service to other providers) } \\
\text { - Availability of tariff setting principles which allow public } \\
\text { participation }\end{array}$ \\
\hline Technical standards & $\begin{array}{l}\text { - Setting of technical standards that are technology-neutral to } \\
\text { accommodate evolving convergence and encourage the entry and } \\
\text { use of new and innovative technologies }\end{array}$ \\
\hline Consumer protection & $\begin{array}{l}\text { Establishment of safeguards to ensure that consumers are protected } \\
\text { against bad business practices, cyber crimes and violations of data } \\
\text { privacy } \\
\text { - Procedures for customers to voice complaints and ensure they } \\
\text { receive adequate response }\end{array}$ \\
\hline Interconnections & $\begin{array}{l}\text { Public availability of procedures for interconnection negotiations, } \\
\text { approval and dispute settlement } \\
\text { - Interconnection to be ensured at any technically feasible point in } \\
\text { the network }\end{array}$ \\
\hline $\begin{array}{l}\text { Universal service and } \\
\text { access }\end{array}$ & $\begin{array}{l}\text { - Implementing universal service/access mechanisms to ensure the } \\
\text { widespread (and affordable) diffusion of communication services }\end{array}$ \\
\hline
\end{tabular}

In this study, the telecommunications sector reform and regulatory evaluation has been conducted through an in-depth interrogation of various pieces of applicable primary and 
secondary legislation (acts, amendments, rules and regulations), sector-specific policies, regulator's published annual reports, sector reviews and reports to multinational bodies. This was followed by presentations of the findings to relevant stakeholders including the responsible ministry, regulator and operators to solicit their views and contributions. Table 2 illustrates the international best practice model or benchmark for regulatory governance and substance, synthesised from the ICT Regulation Toolkit (InfoDev, 2004), the ITU (2011) and the WTO (1996). For each regulatory governance element and for each regulatory substance element, some current best practice standards are specified in the table against which the Lesotho telecommunications sector reform is assessed in Sections 4 and 5.

Another socio-technical framework (Gao and Rafiq, 2009) that explores factors critical for telecommunications sector development is also used to analyse the clarity of roles and functions in regulatory governance (government ministry, regulatory agency, network and service providers) and the effectiveness of pro-competition policy in regulatory substance (licensing, technical standards, inter-connections, universal service and access). Further effort is made to situate the discussion and analysis in the context of a small developing African nation by comparison with other regional countries.

\section{Telecommunications sector reforms in Lesotho}

A summary of the key policy and regulatory reform events in the Lesotho telecommunications history is given in Table 3 . Based on significant changes in national policy, these reforms are grouped in three stages shown in Figure 3 to analyse the social and technological factors (Gao and Rafiq, 2009) responsible for the growth of the sector from 1995 to 2012. The Lesotho telecommunications sector started as a government monopoly with the LTC's infrastructure limited to the wire line delivery of switched voice telephony. During the first stage (1995-1998), the LTC, overseen by the government through the Ministry of Communications $(\mathrm{MoC})$, undertook joint operations, regulatory and policy functions for the telecommunications services as was exclusively provided for by the 1979 Act (GoL, 1979). The indicators in 1995 showed very low network capacity and bare access to telecommunications services with the national telephony capacity of 0.75 lines per 100 people starkly contrasting with the regional average of 3.4 lines (MoC, 1999). In addition to the monopolistic governance, the existing analogue POTS (plain old telephone service) network's inability to support highspeed data transmission and many value-added services impeded economic growth by discouraging investment in other industrial and service sectors. The underlying factor to this abysmal performance by the state-owned telecom provider could be attributed to inappropriate institutional arrangements (poor regulatory governance) and inadequate investment in necessary infrastructure, which relied on dwindling government grants and guaranteed loans for infrastructure development.

A major sector transformation was to follow in 1995 with the advent of the Privatization Act (GoL, 1995a, 1995b) which listed the LTC among the state-owned corporations earmarked for privatisation to take advantage of the technological developments in expanding national telecommunication networks to stimulate socio-economic development. This reflected the regional and global trend towards reforming the sector for the provision of reliable, effective and affordable services, as envisaged by SADC (1996). The 1996 entrance of Vodacom Lesotho (VCL) as the first 
privately-owned mobile network operator in the country set the scene for private participation. It operated a second generation (2G) Global System for Mobile Communications (GSM) network, offering basic voice services. VCL was initially owned by Vodacom Group and GoL (through LTC). The 12\% GoL stake was later sold to a consortium of local private investors called Sekha-Metsi in 1999 when the privatisation process began. Access to services at this stage was restricted to the capital Maseru and a few other major towns with the users mainly being from the high-income group, civil servants and institutional employees.

Table 3 Chronology of regulatory reforms in the Lesotho telecommunications sector

\begin{tabular}{|c|c|c|}
\hline Date & Legislation & Reform \\
\hline 1995 & Lesotho Privatization Act No. 9 of 1995 & $\begin{array}{l}\text { Provision for privatisation of state-owned } \\
\text { infrastructure utilities }\end{array}$ \\
\hline 1995 & Legal Notice No. 103 of 1995 & $\begin{array}{l}\text { Listing of LTC among state-owned entities } \\
\text { lined-up for privatisation }\end{array}$ \\
\hline 1999 & $\begin{array}{l}\text { Lesotho Telecommunications Policy of } \\
1999\end{array}$ & $\begin{array}{l}\text { Provision for independent sector regulation, } \\
\text { promotion of investment and competition }\end{array}$ \\
\hline 2000 & $\begin{array}{l}\text { Lesotho Telecommunications Authority } \\
\text { Act No. } 5 \text { of } 2000\end{array}$ & $\begin{array}{l}\text { Establishment of Lesotho Telecommunications } \\
\text { Authority (LTA) and restructuring of the } \\
\text { incumbent national operator (LTC) }\end{array}$ \\
\hline 2001 & $\begin{array}{l}\text { Lesotho Telecommunications Authority } \\
\text { (Amendment) Act No. } 7 \text { of } 2001\end{array}$ & $\begin{array}{l}\text { Modified definition of 'telecommunication' } \\
\text { and provided for operators' code of conduct }\end{array}$ \\
\hline 2005 & Lesotho ICT Policy of 2005 & $\begin{array}{l}\text { Provision for extending regulation to ICT, } \\
\text { broadcasting and postal services }\end{array}$ \\
\hline \multirow[t]{3}{*}{2006} & $\begin{array}{l}\text { Lesotho Telecommunications Authority } \\
\text { (Amendment) Act No. } 4 \text { of } 2006\end{array}$ & $\begin{array}{l}\text { Substituting 'Info-communications' for } \\
\text { 'telecommunications' }\end{array}$ \\
\hline & & $\begin{array}{l}\text { Replacing the 'appointing authority' with the } \\
\text { 'Minister' }\end{array}$ \\
\hline & & Raising Board members from five to seven \\
\hline 2007 & Legal Notice No. 31 of 2007 & $\begin{array}{l}\text { Substituting 'communications' for } \\
\text { 'info-communications', leading to the current } \\
\text { Lesotho Communications Authority (LCA) }\end{array}$ \\
\hline 2008 & $\begin{array}{l}\text { Lesotho Communications Policy of } \\
2008\end{array}$ & $\begin{array}{l}\text { Institutional framework for regulation of } \\
\text { telecommunications, broadcasting and postal } \\
\text { sectors (converged environment) }\end{array}$ \\
\hline 2012 & Communications Act No. 4 of 2012 & $\begin{array}{l}\text { Positioning of LCA as an independent } \\
\text { converged communications sector regulator }\end{array}$ \\
\hline
\end{tabular}

The MoC (1999) published the Telecommunications Policy, in accordance with the SADC model telecommunication bill (SATCC-TU, 1999) to kick start the second stage of reform (1999-2004). Informed by the policy, the GoL enacted the 2000 Act, as the principal legislation, to establish an autonomous and independent LTA as a body corporate with the powers to regulate telecommunication services (GoL, 2000). The LTA had the duty to develop, promote and supervise the provision of efficient local, national, regional and international telecommunication services in Lesotho. The act also repealed its 1979 predecessor and provided for the restructuring of the incumbent national operator. The incumbent LTC was finally incorporated as Lesotho Telecom (TL) in November 2000, owned by a consortium called Mountain Communications (70\%) with 
the government retaining partial ownership (30\% stake). The LTA also licensed a new GSM network operator, Econet Ezi-cel Lesotho (EEL), which was a subsidiary of TL and co-owned by Econet Wireless. In 2001, the LTA (amendment) act provided a short modification to the interpretation of 'telecommunication' and added a prescription of code of conduct and penalties for non-compliance with the code in the principal law (GoL, 2001).

Figure 3 Three stages of Lesotho's telecommunication transformation (see online version for colours)

\begin{tabular}{|c|c|c|c|}
\hline & $\begin{array}{c}\text { Stage 1 } \\
(1995-1999)\end{array}$ & $\begin{array}{c}\text { Stage 2 } \\
(1999-2004)\end{array}$ & $\begin{array}{c}\text { Stage } 3 \\
\text { (2005-present) }\end{array}$ \\
\hline $\begin{array}{l}\text { Government } \\
\text { Institutions }\end{array}$ & $\mathrm{MoC}$ & $\begin{array}{l}\text { MoC } \\
\text { LTA }\end{array}$ & $\begin{array}{l}\text { MCST } \\
\text { LCA }\end{array}$ \\
\hline $\begin{array}{l}\text { Network \& } \\
\text { Service } \\
\text { Providers }\end{array}$ & $\begin{array}{l}\text { LTC (fixed) } \\
\text { VCL (mobile) }\end{array}$ & $\begin{array}{c}\text { TL (fixed) } \\
\text { VCL (mobile) } \\
\text { EEL (mobile) }\end{array}$ & $\begin{array}{l}\text { ETL (TL \& EEL - } \\
\text { fixed \& mobile) } \\
\text { VCL (mobile) }\end{array}$ \\
\hline Users & $\begin{array}{l}\text { High income } \\
\text { groups } \\
\text { Restricted to } \\
\text { major towns }\end{array}$ & $\begin{array}{l}\text { Middle / working } \\
\text { class } \\
\text { Most big towns } \\
\text { and villages }\end{array}$ & $\begin{array}{l}\text { Mobile services } \\
\text { reached majority } \\
\text { of society, } \\
\text { including rurals }\end{array}$ \\
\hline Technology & $\begin{array}{l}\text { Networks: POTS } \\
\text { \& GSM } \\
\text { Services: Voice }\end{array}$ & $\begin{array}{l}\text { Networks: POTS, } \\
\text { WLL \& GSM } \\
\text { Services: Voice \& } \\
\text { SMS }\end{array}$ & $\begin{array}{l}\text { Networks: ADSL, GSM, } \\
\text { GPRS, EDGE \& HSDPA } \\
\text { Services: Voice, SMS \& } \\
\text { Data }\end{array}$ \\
\hline
\end{tabular}

The licence for the newly partially-privatised TL initially provided for exclusivity or temporary monopoly for a period of five years to February 2006 on the fixed-line services and on international traffic routing in an effort by the government to entice investors. In order to provide acceptable penetration level, TL's fixed line target was set at 25,000 by 2003 and 10,000 more per year. This protective move, which deviated from the pro-competition policy of 1999 , awkwardly allowed competition only in the mobile sector even under the supposedly liberalised market, thereby seriously delaying the real benefits that could have been brought by competition (Wallsten, 2001). The two mobile operators (VCL and EEL) introduced the low-cost SMS (short message service) in addition to the basic voice that TL was also offering. The telecommunication services prices reduced significantly during this time and usage spread to the middle and working class, with network coverage also extending to small towns and big villages around the country, spurred by the mobile networks which have proved to be an attractive option for many developing countries.

The third stage began in 2005, with the new Ministry of Communications, Science and Technology (MCST) publishing the ICT Policy for Lesotho (MCST, 2005). The policy stipulated the restructuring of the regulator by broadening its functional scope to cover telecommunications, ICT, broadcasting as well as postal services. Subsequently, the 2006 amendment act was published (GoL, 2006) and followed by the 2007 notice to substitute 'Communications' wherever 'Info-Communications' appeared in the 2006 
amendment (Attorney General, 2007). Henceforth, the regulator became known as the Lesotho Communications Authority (LCA). Nevertheless, this amendment also gave the responsible minister powers over the regulator as the appointing authority and compromised its independence. For instance, when the exclusivity era was supposed to end in 2006, TL had failed to meet its target as the fixed line service virtually stagnated after its expansion programme based on wireless local loop (WLL) dismally failed and had to face penalties from the regulator. However, in a move that left the telecommunication sector disenchanted, particularly TL's main competitor VCL, the government controversially intervened to quash the penalties and coerced the regulator to extend TL's exclusivity by 12 months (LTA, 2006).

In 2008, the GoL formulated the Communications Policy which established an institutional framework for the regulation of telecommunications, broadcasting and postal sectors (MCST, 2008). The policy also reflects the convergence of services based on the internet and fosters the establishment of a Universal Service and Access Fund (USAF) to promote access to communication services in remote areas of the country. Drawing from the 2008 policy document, the 2012 Communications Act was promulgated to provide for regulation of telecommunications, broadcasting and postal sectors (GoL, 2012). The number of network operators was reduced from three (TL, VCL and EEL) to two (ETL and $\mathrm{VCL}$ ) as the fixed-line TL and mobile EEL consolidated operations and merged in 2008 .

After the TL's exclusivity in fixed line services and international traffic routing ended, private sector investment in this sector was encouraged, leading to a more competitive market during the third stage. Major network upgrades using newer technologies such as ADSL (asymmetrical digital subscriber line), 2.5G GPRS (general packet radio service), 2.75G EDGE (enhanced data rate for GSM evolution) and $3 \mathrm{G}$ HSDPA (high-speed downlink packet access) were put in place to support high-speed data transmission (mobile internet) and many value-added services (money transfer, exam results, advertising, etc.). In addition, the establishment of USAF in 2009 to assist operators to expand their networks to rural and under-served areas also spurred the industry, realised exponential growth and overall teledensity reached about $78 \%$ of the society in 2012.

\section{Evaluating regulatory governance}

\subsection{Institutional framework}

The separate roles and responsibilities of the government and the regulator have been clearly defined in the various sector policies (1999, 2005 and 2008), the founding LTA Act 2000 (as amended) and the subsequent Communications Act 2012, with all enshrining the principle of independence of the regulator. Section 3.1.1 of the 2008 Policy specifies the principal functions of the government, through the responsible ministry, as establishment of basic policy for the communications sector, representing Lesotho on international matters relevant to the sector and ensuring that the regulator acts consistently with law and established policy. The 2012 Act, under Part II, also recognises the regulator as independent with the powers to make decisions in a manner free from political interference, influence or considerations. The regulatory independence is consistent with international best practice as advocated by the assessment approach in 
Section 2. Such regulatory independence is essential for protection from populist pressure and to ensure the confidence of both private investors and foreign donors who play a critical role in the sector development. However, the minister responsible for communications has in the past participated in, or sought to influence, the decisionmaking processes of the regulator regarding operational and technical matters, the TL's exclusivity saga mentioned earlier being a point in case.

The law, through Part III of the 2012 Act, further embodies provisions designed to balance regulatory independence and accountability by giving the powers of the regulator to be exercised by the board of directors and the chief executive officer (CEO). The responsible minister nominates six non-executive directors to serve on the board, including the chairperson, after soliciting recommendations of qualified persons with diverse and appropriate professional backgrounds and skills covering economics, accounting, telecommunications technology, engineering, public policy, business practice, finance and law. Board members serve for a three-year term and may only be removed for cause. They are eligible for re-nomination for additional three-year terms. Their terms of office do not coincide with the terms of government and are staggered to ensure continuity. The minister also appoints the CEO on a three-year contract, following recommendation by the board. The CEO becomes an executive director and is also eligible for a contract extension and may only be removed for cause. Nevertheless, the fact that there is a high level of governmental involvement through ministerial appointments of board members and CEO puts the independence of the regulator into question. The Transformation Resource Centre (TRC), a non-governmental organisation in Lesotho, once raised an issue of partisan relationship with the composition of the LCA board in 2008, casting a dull shadow on its legitimacy and acceptability of its decisions (TRC, 2008). Such ministerial appointments, if subjected to parliament's scrutiny for confirmation, would enhance the credibility and legitimacy of the process.

The 2008 Policy, under Section 3.1.2, provides avenues to review the decisions made by the regulator for any aggrieved party. First, the party may seek reconsideration from the regulator's board. If the regulator does not alter its decision, it is required to justify its action in writing. If the reconsideration result is not satisfactory, a review by the minister may be requested. The last stage of the review process, if the minister upholds the regulator's decision, is to seek judicial intervention from the courts of law. LCA issues calls for public consultations and publishes key decisions (e.g., on tariffs, license renewals, etc) and none of its decisions have been appealed in the courts to date.

LCA has made and published applicable rules and regulations (LTA, 2000, 2001, 2004, 2007; LCA, 2008b, 2009b) that lead to efficient, coherent and fair decision making open to all interested parties. For all regulatory processes to maintain transparency and participation, decision makers should be provided with adequate, accurate and fully tested information. With the exclusion of emergency cases, no decision is made without proper legal notice informing all parties to the matter. A full schedule with a timeline for the matter under consideration is made publicly available (usually at the regulator's office and on its website) and all interested parties are accorded opportunity to make inputs. All documents relied upon in making decisions are presumed to be available to the public unless the regulator rules otherwise (mainly on grounds of commercial confidentiality). This prohibits arbitrariness and dishonesty in decision-making, leading to consistent and predictable determinations on similar matters. 


\subsection{Regulator structure}

LCA is the statutory body with the primary responsibility for regulation of the communications sector in Lesotho. It is an independent/autonomous regulatory agency that was established in June 2000 by the LTA Act 2000 (as amended), where it derives its legal authority to carry out economic and technical regulation (tariff approval, quality of service, consumer protection, competition management, investment promotion, setting technical standards, enforcement and issues of increasing access). The LCA Act 2012 is currently the applicable regulatory law and there is no separate telecommunications sector law.

The current LCA board of directors is composed of the CEO and six members who are non-executive directors, with skills ranging from business, banking and legal. The recently retired board chairman, who left at the end of the 2010/11 financial year, had been at helm of LCA for three consecutive terms (nine years). In order to adopt and promote the principles of good corporate governance in its business as well as that of the regulator, the board has three committees, finance and audit (FAC), human resources and remuneration (HRRC) and universal access fund (UAFC). These committees include professionals, apart from the board members, with requisite skills, experience and abilities to guide the work of the regulator in these areas.

Since its establishment, the LCA has had only two CEOs and neither of them has served less than a complete term of three years. The incumbent CEO was appointed in 2003 and is on his fourth term as the head of the regulatory authority. The executive committee comprises four directors who head the main departments of Regulatory Resources and Technologies, Economics and Market Development, Licensing, Compliance and Consumer Affairs and Corporate Services. The four departments, together with the office of the CEO house the total staff complement of 31 with the required regulatory capabilities and skills that include eight engineers, five economists and five lawyers.

There have been major changes in the responsibilities of LCA since its inception in 2000. In addition to the telecommunications services, it began regulating the broadcasting sector since 2004 (LTA, 2004) and will soon commence regulation of the postal sector as provided for by the 2008 Policy and the 2012 Act. The percentage of staff effort that is currently dedicated to the telecommunications sectors is almost $100 \%$. It is envisaged that adoption of a converged regulatory regime will result in significant administrative efficiencies as a number of regulatory functions (licensing, consumer protection, etc.) are relevant in all three sectors.

\subsection{Regulator's financial resources}

Part IV of the Communications Act 2012 sets out the strategy for the regulator to attain sufficient funding for its operations to ensure its financial and administrative independence. LCA prepares its own annual budget for overall spending which has to be approved by the board. Nevertheless, the regulator is also required to submit the budget to the responsible minister for further approval not less than two months before the beginning of its financial year (1st April). The government subvention is issued as and when it is necessary and subsidy in the form of capital grants is given on an annual basis. However, since the LCA's formative stages, regulatory fees (application, license, spectrum and royalty) have always accounted for more than $75 \%$ of the regulator's 
income. Notably in $2008 / 09$ to $2010 / 11$, the LCA's budget has been made up almost entirely of payments by regulated entities in the form of regulatory fees as illustrated by Figure 4. The funds generated are for the exclusive use of the regulator to meet the cost of its operations and any surplus accrued should be used for the promotion and development of the communications sector.

The regulator is also required by law to adhere to international accounting standards and to publish an annual report on its activities and audited financial statements within six months (by 30th September) after the previous financial year end. The office of the Auditor General is the designated government audit office required to audit the accounts of the regulator or appoint an independent, qualified and internationally recognised accounting firm to carry out the audit. The regulator has produced the annual reports with unqualified audited financial statements over the years timeously (LTA, 2002, 2003; LCA, 2007, 2008a, 2009a, 2010a), with the exception of the 2010/11 report (LCA, 2011) being released in March 2012, six months after the deadline. Subsequent to publication of the annual report, the minister responsible for communications presents it before parliament to account on the regulator's activities and financial management. Accountability could also be enhanced by the actual regulator's appearance before a parliamentary portfolio committee.

Figure 4 LCA's financial performance (see online version for colours)

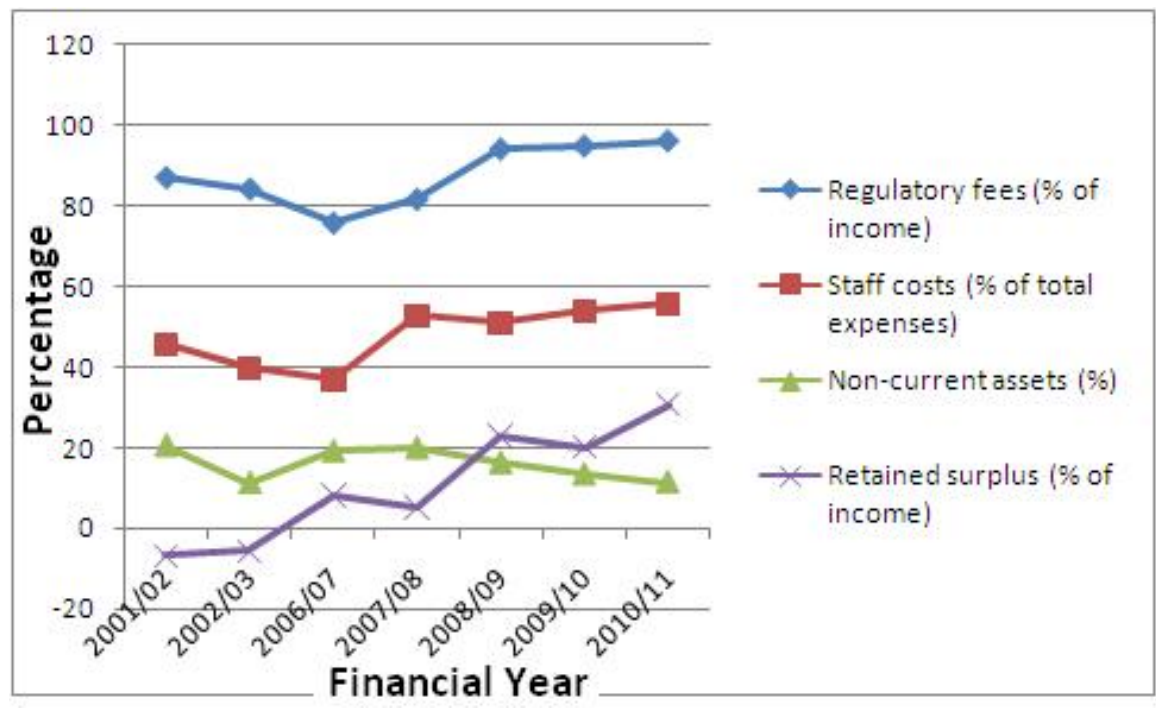

Figure 4 depicts a very healthy financial state for the regulator. In $2010 / 11$, over $96 \%$ of LCA's income came from the regulatory fees composed of spectrum fees $(42.5 \%)$ and royalty fees $(52.5 \%)$ levied mainly from the two network operators (VCL and ETL). An issue of sustainability may arise if the said operators' performance deteriorates or one of them goes into financial difficulties. However, the staff costs are at sustainable level, below $60 \%$ of the total expenditure. In addition, the regulator has majority of its assets as cash and cash equivalents in current accounts and short term deposits, as non-current assets accounted for only $11.58 \%$ in $2010 / 11$. The retained surplus also shows a steady increase and, together with the current assets, the regulator remains a going concern. 


\section{Evaluating regulatory substance}

The LCA regulates market entry and conduct through licensing, tariff approvals, management of scarce resources (radio spectrum, telephone numbering), approval of terminal equipment, setting technical quality of service standards and overseeing interconnections and network access between operators and new market entrants as briefly expressed in Table 4.

Table 4 Principal functions of LCA

\begin{tabular}{|c|c|}
\hline Functions & Evidence \\
\hline Licensing & $\begin{array}{l}\text { Licensing of telecommunications services providers } \\
\text { (VCL, ETL, BTL) }\end{array}$ \\
\hline Tariff regulation & $\begin{array}{l}\text { Guidelines available; Operators submit request for tariff structures } \\
\text { and LCA approves tariff levels after public consultations }\end{array}$ \\
\hline \multirow{3}{*}{$\begin{array}{l}\text { Management of scare } \\
\text { resources }\end{array}$} & Radio Frequency Spectrum Policy 2008 \\
\hline & $\begin{array}{l}\text { Automated Frequency Management System (AFMS) for planning } \\
\text { and assignment }\end{array}$ \\
\hline & National numbering plan and numbers for premium rate services \\
\hline $\begin{array}{l}\text { Standards and approval } \\
\text { of equipment }\end{array}$ & $\begin{array}{l}\text { LCA type-approves equipment, inspects and evaluates technical } \\
\text { specifications in line with CRASA, ITU and ETSI }\end{array}$ \\
\hline \multirow{2}{*}{$\begin{array}{l}\text { Monitoring performance } \\
\text { of service providers }\end{array}$} & Accounting systems. Periodic reporting requirements. \\
\hline & Spectrum audits, drive tests for signal spillage \\
\hline $\begin{array}{l}\text { Interconnection/network } \\
\text { access }\end{array}$ & LCA has no mandate; Operators sign agreement between themselves \\
\hline $\begin{array}{l}\text { Consumer empowerment } \\
\text { and protection }\end{array}$ & $\begin{array}{l}\text { LCA has adopted a Consumer Bill of Rights policy and developed } \\
\text { Communications Sector Consumer Complaint Procedure }\end{array}$ \\
\hline Universal service & Established a Universal Access Fund (UAF) \\
\hline
\end{tabular}

\subsection{Legal and regulatory issues}

Part II of the 2012 Act gives LCA statutory powers to license all private and public telecommunications services providers in Lesotho for provision of domestic or international voice and data traffic. By the end of 2012, 12 years after market liberalisation, only two converged communications services providers have been licensed by LCA; VCL (mobile services) and ETL (both fixed and mobile services). Another operator, Bethlehem Technologies Lesotho (BTL), has been licensed to provide international bandwidth via satellite since 2001/02. The regulator also currently holds licences for four internet service providers (ISPs), two television and 12 sound broadcasters, comprising public, private, commercial and community enterprises. The LCA has adopted a consumer bill of rights policy that outlines the basic principles of consumer protection and education in the communications sector and subsequently developed the consumer complaint procedure guidelines (LCA, 2010b). The document provides guidance to consumers on steps to take when filing complaints against providers who offer poor services or when elevating their grievances to the regulatory agency. 


\subsection{Technical regulation}

The primary legislation provides for LCA to manage Lesotho's radio frequency spectrum and it is responsible for its planning, assignment and monitoring. As a result, LCA invested in an advanced AFMS to continue to revise and update the National Frequency Allocation Plan to align it with regional (SADC) and International Telecommunication Union (ITU) band plans, coordinate and assign spectrum for various communications services. LCA also conducts audit of transmission sites in order to promote interferencefree radio-communications and carries out inspections of operator premises or operational sites to ensure compliance with licence conditions. Through the memorandum of understanding signed with the Independent Communications Authority of South Africa (ICASA), LCA further monitors the level to explore ways of reducing the signal spillage between Lesotho and SA along the common border areas.

The regulator is responsible for management of changes in the national numbering plan for submission to ITU and dissemination of changes in other international numbering plans and routing tables for switching. In line with adopted technical standards from recognised organisations such as ITU and ETSI (European Telecommunications Standards Institute), LCA type approves communications equipments for compliance with a minimum set of regulatory, technical and safety requirements. Interconnection agreements are negotiated by the parties involved and only brought to LCA for approval in line with the legislation, to ensure non-dominant tendencies.

\subsection{Economic and tariff regulation}

Pricing and tariff requests for new products and services and amendment to existing ones by the operators are submitted to the LCA and approval is only granted after public consultations. The methodology LCA applies in making its determination is not available, but the general trend is the reduction in tariffs in the considered applications during the 2010/11 financial year. The practice in regulatory systems is to follow the revenue requirement and return on investment methodology. In short, the method considers the operator's regulatory asset base, depreciation, operations and maintenance costs, taxes, new approved investment and debt/equity ratio. The benchmarking is done based on approved operator's budget and the actual expenditure verified by audited financial statements to ensure cost reflectivity in tariffs.

\subsection{Universal service and access}

The LCA launched the UAF at the beginning of the 2009/10 financial year to accelerate the development of communications services in remote and unserved areas considered non-viable by service providers, pursuant to Section 48 of the LTA Act 2000. The revenue for the fund were to mainly comprise an initial contribution of M10 million and subsequent contribution of $25 \%$ of annual surplus from the regulator and annual contribution of $1 \%$ of net operating income (NOI) of licensed network operators (LCA, 2009 b). Basic voice telephony has been identified as the primary service to be provided under the fund with secondary services as internet access and broadcasting signal transmission. After two years of the fund's operations, significant results have been achieved in providing subsidies to network operators in rolling out infrastructure. The 
seven projects completed involved construction of 13 base transceiver stations (BTS) sites in various districts, providing network coverage to more than 27,000 people in 146 villages around the country.

A comparison of Lesotho and close-knit neighbouring countries in the Southern African Customs Union (SACU) is drawn in Figure 5 based on the annual growth rates experienced between 2001 and 2011 in the overall telecommunications sector (ITU, 2013). Lesotho attained the highest average growth rate of $39 \%$ over the ten year period with phenomenal growth rates of $79 \%$ and $112 \%$ recorded in the first two years immediately following the transition to telecommunication sector transformation in 2000 . These favourable rates can be attributed to the private investment that accompanied the advent of TL and EEL in addition to an aggressive strategy by VCL to retain its market share at the time. The growth dipped considerably to $-3 \%$ in 2003 owing to loss in fixed line business as TL lost ground to its mobile competitors owing to WLL failure mentioned earlier and customers actually terminated their connections. Nevertheless, cognisant of the critical role telecommunications sector plays in promoting socioeconomic development, the Lesotho case study has presented a strong relationship between high market growth and the central aspect of good regulatory governance and substance.

Figure 5 Telecommunications growth rates in SACU countries (see online version for colours)

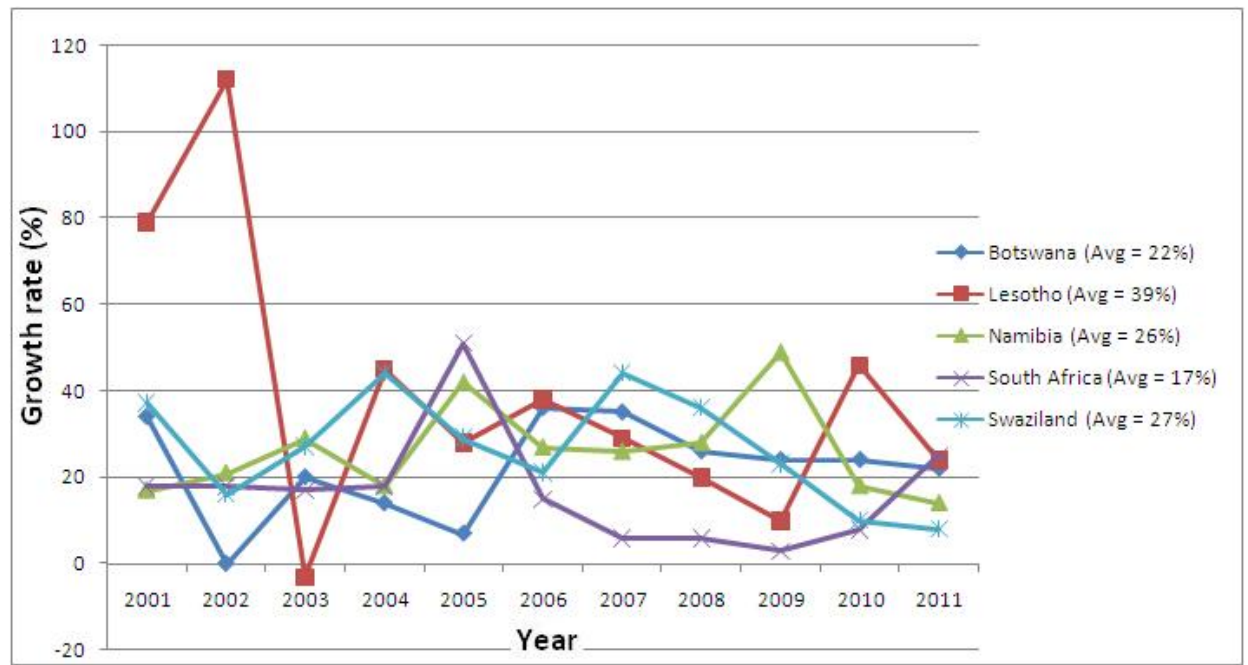

\section{Conclusions}

With very little published research to explain Lesotho's telecommunications sector growth, this article has provided an insight into the reforms undertaken to liberalise the Lesotho telecommunications sector in the last two decades which resulted in the establishment of the regulator (LCA), privatisation of state-owned monopoly (LTC), entrance of other private entities (ETL and VCL) and commendable market growth linked to economic development. In terms of regulatory governance and substance which are essential to the growth of the telecommunications sector, the resulting regulated 
sector reflects favourable conformance to international best practices. The primary legislative framework clearly establishes the regulator as a statutory body distinct from government and sets out LCA's roles and functions with requisite powers such as full licensing authority, managing the radio spectrum, approval and enforcement of tariffs and fees, development and enforcement of technical standards, arbitration of interconnections, resolution or mediation of consumer complaints, monitoring and promotion of competition and facilitation of universal access to communications services. The regulator also develops subsidiary legislation (rules and regulations) and LCA issues rules while the minister issues regulations to set out implementation procedures for licensing, tariff setting and technical standards processes. The decision-making independence of the regulator is safeguarded by the legislation, subject to issues of ministerial appointments at the governance level, and none of its key decisions published to date have been appealed in the courts. Its financial independence is enhanced by its ability to get more than $95 \%$ of its revenue from regulatory fees and its prudent financial management may lead it to continue as a going concern.

Market access to the telecommunications sector is still limited to two operators, and the status quo may remain because of the country's small population and economy. Nevertheless, the overall teledensity, demonstrating a tremendous improvement in access to services by the population, has increased from $0.75 \%$ in 1995 to about $78 \%$ in 2012 . Building on these preceding reforms and established regulatory structures and content, future study will assess the performance of the sector and evaluate the regulatory impact on various sections of society in terms of among others, affordability of communication services, infrastructure robustness and network coverage, operators' efficiency and financial viability, economic development through self-employment (pay phones, recharge vouchers) and small businesses (internet cafes, advertising agencies) and value-added services (internet banking, money transfer, exam results, etc). Finally, challenges facing the communications sector regulation will be highlighted together with recommendations on how they can be addressed.

\section{References}

Attorney General (2007) Legal Notice No. 31 of 2007.

BoS (2013) Lesotho Bureau of Statistics, BoS official website [online] http://www.bos.gov.ls.

Brown, A.C., Stern, J., Tenenbaum, B. and Gencer, D. (2006) Handbook for Evaluating Infrastructure Regulatory Systems, The World Bank, Washington DC.

Fink, C., Mattoo, A. and Rathindran, R. (2003) 'An assessment of telecommunications reform in developing countries', Information Economics and Policy, Vol. 15, No. 4, pp.443-466.

Gao, P. and Rafiq, A. (2009) 'The transformation of the mobile telecommunications industry in Pakistan: a developing country perspective', Telecommunication Policy, Vol. 33, Nos. 5-6, pp.309-323.

Gasmi, F. and Virto, L.R. (2010) 'The determinants and impact of telecommunications reforms in developing countries', Journal of Development Economics, Vol. 93, No. 2, pp.275-286.

Gillwald, A. (2005) 'Good intentions, poor outcomes: telecommunications reform in South Africa', Telecommunications Policy, Vol. 29, No. 7, pp.469-491.

GoL (1979) Lesotho Telecommunications Act No. 12 of 1979.

GoL (1995a) Lesotho Privatization Act of 1995.

GoL (1995b) Legal Notice No. 103 of 1995. 
GoL (2000) LTA Act No. 5 of 2000.

GoL (2001) LTA (amendment) Act No. 7 of 2001.

GoL (2006) LTA (amendment) Act No. 4 of 2006.

GoL (2012) Communications Act No. 4 of 2012.

Henten (2004) 'Telecommunications development in Africa: filling the gap', Telematics and Informatics, Vol. 21, No. 1, pp.1-9.

InfoDev (2004) InfoDev/ITU ICT Regulation Toolkit - Module 1: Regulating the Telecommunications/ICT Sector: Overview [online] http://www.ictregulationtoolkit.org (accessed 01 March 2013).

ITU (2011) in Blackman, C. and Srivastava, L. (Eds.): Telecommunications Regulation Handbook, 10th anniversary ed., [online] http://www.infodev.org/en/Document.1057.pdf (accessed 01 March 2013).

ITU (2013) ICT Facts and Figures, ITU [online] http://www.itu.int/en/ITU-D/Statistics/Pages/stat/default.aspx (accessed 14 August 2013).

Jayakar, K. and Martin, B. (2012) 'Regulatory governance in African telecommunications: testing the resource curse hypothesis', Telecommunications Policy, Vol. 36, No. 9, pp.691-703.

Kenny, C. and Keremane, R. (2007) 'Towards universal telephone access: market progress and progress beyond the market', Telecommunications Policy, Vol. 31, Nos. 3-4, pp.155-163.

LCA (2007) Annual Report 2006/07, LCA official website [online] http://www.lca.org.ls.

LCA (2008a) Annual Report 2007/08.

LCA (2008b) LCA (Licensing Fees) Rules 2008.

LCA (2009a) Annual Report 2008/09.

LCA (2009b) LCA (Universal Access Fund) Rules 2009, Legal notice no. 31 of 2009.

LCA (2009c) The State of Communications Sector and ICT Indicators in Lesotho, 1st ed., Maseru, Lesotho.

LCA (2010a) Annual Report 2009/10.

LCA (2010b) Communications Sector Consumer Complaint Procedure, Maseru, Lesotho.

LCA (2011) Annual Report 2010/11.

LCA (2012) Annual report 2011/12.

Levy, B. and Spiller, P.T. (1994) 'The institutional foundations of regulatory commitment: a comparative analysis of telecommunications regulation', Journal of Law, Economics, \& Organization, Vol. 10, No. 2, pp.201-246.

LTA (2000) LTA (Administrative, Procedural and Service Provision) Rules 2000, Legal notice no. 212 of 2000.

LTA (2001) LTA Regulations 2001, Legal notice no. 34 of 2001.

LTA (2002) Annual Report 2001/02.

LTA (2003) Annual Report and Financial Statements 2002/03.

LTA (2004) LTA (Broadcasting) Rules 2004, Legal notice no. 71 of 2004.

LTA (2006) Telecom Lesotho's Exclusivity [online] http://www.lca.org.ls/images/documents/200602-06_TL_Exclusivity_Extension.pdf (accessed 14 August 2013).

LTA (2007) LTA Broadcasting Classification Regulations 2007, Legal notice no. 19 of 2007.

Makhaya, G. and Roberts, S. (2003) 'Telecommunications in developing countries: reflections from the South African experience', Telecommunications Policy, Vol. 27, Nos. 1-2, pp.41-59.

McCormick, P.K. (2003) 'Telecommunications reform in Southern Africa: the role of the Southern African Development Community', Telecommunications Policy, Vol. 27, Nos. 1-2, pp.95-108.

MCST (2005) ICT Policy for Lesotho 2005, Ministry of communications, Science and Technology, Maseru, Lesotho. 
MCST (2008) Lesotho Communications Policy 2008, Ministry of Communications, Science and Technology, Maseru, Lesotho.

MoC (1999) Lesotho Telecommunications Policy 1999, Ministry of Communications, Maseru, Lesotho.

SADC (1996) SADC Protocol on Transport, Communications and Meteorology, Maputo, Mozambique.

SATCC-TU (Southern Africa Transport and Communications Commission Technical Unit) (1999) SADC Telecommunication Policies \& Model Telecommunication Bill, Maputo, Mozambique.

Stovring, J. (2004) 'The Washington Consensus in relation to the telecommunication sector in African developing countries', Telematics and Informatics, Vol. 21, No. 1, pp.11-24.

TRC (2008) Broadcasting Self-Correction Body Mooted [online] http://trc.org.ls/trc_programmes/info_comm/new\%20Communications\%20Policy.htm (accessed 14 August 2013).

UN (2000) United Nations Millennium Development Goals [online] http://www.un.org/millenniumgoals (accessed 01 March 2013).

Wallsten, S.J. (2001) 'An econometric analysis of telecom competition, privatization and regulation in Africa and Latin America', The Journal of Industrial Economics, Vol. 49, No. 1, pp.1-19.

Waverman, L. and Koutroumpis, P. (2011) 'Benchmarking telecoms regulation - the telecommunications regulatory governance index (TRGI)', Telecommunications Policy, Vol. 35, No. 5, pp.450-468.

WTO (1996) Telecommunications Services: Reference Paper [online] http://www.wto.org/english/tratop_e/serv_e/telecom_e/tel23_e.htm (accessed 01 March 2013). 